\title{
УДК 373.5.016:004(477)
}

\section{Петренко Сергій Вікторович}

кандидат педагогічних наук, старший викладач кафедри інформаційно-комунікаційних технологій та методики викладання інформатики

Рівненський державний гуманітарний університет, м. Рівне, Україна

ORCID ID 0000-0002-5311-0743

petrenko.zd@gmail.com

\section{ОПТИМІЗАЦІЯ Й АНАЛІЗ РЕЗУЛЬТАТІВ ВИКОРИСТАННЯ LMS MOODLE У СИСТЕМI ЗМIШАНОГО НАВЧАННЯ В УНІВЕРСИТЕТІ}

\begin{abstract}
Анотація. У статті обгрунтовано теоретичні засади е-навчання, дистанційного та змішаного навчання; проаналізовано досвід використання змішаного стилю викладання курсу «Візуальне програмування», де за платформу було використано LMS Moodle. 3'ясовано позитивні й негативні аспекти реалізації курсу за допомогою веб-аналітики. Проаналізовано: відвідуваність курсу й успішність студентів; співвідношення потраплянь студентів на сайт, де розміщений курс; використання он-лайн уроків, он-лайн тренінгів 3 окремих тем; кількість часу, проведеного на ресурсі студентами; сумарну активність студентів на сайті; кореляцію між унікальними відвідуваннями і кількістю переглянутих сторінок курсу; відвідування ресурсу з мобільних пристроїв; операційні системи, з яких відбувалося звернення до ресурсу; співвідношення браузерів, які використовувались для роботи з ресурсом; відвідування ресурсу за місцевим часом.
\end{abstract}

Ключові слова: е-навчання; дистанційне навчання; змішане навчання; LMS Moodle; онлайн уроки; мобільні пристрої; учитель інформатики початкової школи.

\section{1. ВСТУП}

Постановка проблеми. Використання сучасних інформаційно-комунікативних, електронних технологій у поєднанні з педагогічним досвідом дасть змогу підняти на більш якісний рівень вищу освіту в Україні. Сучасні навчальні заклади все частіше запроваджують е-навчання (e-learning) як дієву можливість поширення знань, що реалізується на різноманітних платформах забезпечення функціонування дистанційної освіти (Learning Space, WebTycho Мерилендського університету США, платформа «Прометей», «Аванта», Joomla, Moodle та ін.) [1]. На сьогодні існує постійна конкуренція між декількома системами управління навчанням (LMS) для дистанційного навчання за збільшення присутності на ринку послуг. Moodle - це одна 3 найбільших LMS із відкритим програмним кодом, на якій станом на серпень 2016 зареєстрована база користувачів близько 90 млн. чоловік [2].

Платформа Moodle створює додаткові можливості для впровадження в освітній процес системи дистанційного й змішаного навчання, дає змогу вільного поширення програмного продукту, а також можливість вільного застосування і модифікації продукту в цілому чи його елементів. Середовище LMS Moodle дає змогу не тільки донести до студента навчальний контент, а й сформувати навчальну траєкторію вивчення дисципліни, організувати зворотній зв'язок у формі діалогового спілкування «студент-контент», «студент-викладач», «студент-студент» та забезпечити поетапний контроль знань тощо.

Водночас технологія дистанційного навчання LMS Moodle для підготовки майбутніх учителів в Україні недостатньо проаналізована й систематизована. А застосування у підготовці учителя методик дистанційного навчання студентів технічних спеціальностей і системи підвищення кваліфікації фахівців є недоцільним, 
позаяк основні вимоги підготовки останніх відрізняються від вимог до навчання студентів педагогічних ВНЗ. Тому проблема аналізу й оптимізації системи дистанційної освіти для підготовки майбутніх педагогів є актуальною.

Аналіз останніх досліджень і пуб̆лікацій. Проблема організації дистанційного навчання $\epsilon$ предметом наукових розвідок А. Анісімова, Л. Гозман, Ю. Триуса, I. Герасименка, В. Франчук та ін. [3; 4; 1]. Упровадження інформаційних технологій у систему освіти, теорію і практику організації дистанційного навчання досліджували В. Биков, О. Спірін [5], теорію і практику змішаного навчання вивчали В. Кухаренко, С. Березенська, К. Бугайчук [6], технологічні основи змішаного навчання проаналізувала А. Фандєєва [7]. Різні аспекти використання LMS Moodle у ВН3 упродовж останніх років досліджено Ю. Триусом, О. Щербиною, К. Васильєвою, К. Колос [1; 8; 9], автором пропонованої розвідки [10; 11].

Водночас, досвід упровадження LMS Moodle у систему змішаного навчання у ВНЗ потребує подальших досліджень й узагальнень.

Мета статті полягає у дослідженні оптимізації й аналізі результатів упровадження LMS Moodle у систему навчання педагогічного ВНЗ.

\section{2. ТЕОРЕТИЧНІ ОСНОВИ ДОСЛІДЖЕННЯ}

Запровадження дистанційної освіти в Україні передбачено Національною програмою інформатизації [12], а сутність запровадження відображена в Концепції розвитку дистанційної освіти [13].

Під дистанційним навчанням академік В. Биков розуміє таку форму організації навчального процесу, за якою іï активні учасники (об’єкт і суб'єкт навчання) досягають цілей навчання, здійснюючи навчальну взаємодію принципово і переважно на відстані [5].

У сучасній системі вищої освіти простежується тенденція інтенсивного розвитку так званого «змішаного» навчання. Під змішаним навчанням (blendedlearning) мається на увазі об'єднання так званих формальних засобів навчання (традиційні засоби «класно-урочної системи»), а саме: роботи в аудиторіях, вивчення теоретичного матеріалу - 3 неформальними (засоби електронного навчання), наприклад, обговоренням за допомогою електронної пошти й Інтернет-конференцій. Змішана форма навчання органічно поєднує в собі як денні (очні), так і дистанційні форми навчання. Якщо дистанційне навчання здійснюється тільки за допомогою Інтернету, то змішане навчання передбачає як дистанційне вивчення теоретичного матеріалу, освоєння практичних аспектів у формі денних занять чи дистанційно, так і здачу іспиту (заліку) або виконання випускної роботи.

Українські учені А. Стрюк, Ю. Триус, В. Кухаренко визначають змішане навчання як цілеспрямований процес здобування знань, набуття вмінь і навичок в умовах інтеграції аудиторної і позааудиторної навчальної діяльності суб'єктів освітнього процесу на основі впровадження і взаємного доповнення технологій традиційного, електронного, дистанційного та мобільного навчання за наявності самоконтролю студента за часом, місцем, маршрутами та темпом навчання [6].

Змішана модель навчання - це модель використання розподілених інформаційноосвітніх ресурсів в стаціонарному навчанні із застосуванням елементів асинхронного й синхронного дистанційного навчання. Практикується як елемент стаціонарного навчання в проведенні аудиторних занять і в самостійній роботі студентів. Тобто змішане навчання успадковує переваги дистанційного навчання й виключає його недоліки [14]. 
У сучасних умовах впровадження змішаної форми навчання $\epsilon$ найбільш прийнятним, при цьому найчастіше використовується так звана «гнучка модель»модель, у якій здебільшого використовується он-лайн платформа, викладач підтримує студентів у міру потреби, час від часу працює з невеликими групами або 3 одним студентом. За цієї моделі онлайн складова $є$ основою навчання студентів, навіть якщо певна діяльність і відбувається офлайн. Студенти працюють за індивідуальним, гнучким графіком, який включає різні формати навчання. Викладач доступний для будь-яких консультацій у будь-який час, і студенти вчаться, здебільшого, відповідно до їхніх індивідуальних освітніх потреб, а також темпу і ритму освоєння навчального матеріалу.

Оскільки більшість вітчизняних ВНЗ використовують для організації та технічного забезпечення дистанційного й змішаного навчання відкриту освітню платформу LMS Moodle, ми теж надаємо перевагу цій платформі навчання і перейшли на використання безкоштовної платформи LMS Moodle при викладанні навчальних дисциплін майбутнім учителям початкової школи.

Аналіз та узагальнення досвіду організації й упровадження LMS Moodle у систему підготовки учителів інформатики початкової школив окремих дисциплінах пропонуємо нижче.

\section{3. РЕЗУЛЬТАТИ ДОСЛІДЖЕННЯ}

У використанні змішаного стилю викладання предмету для майбутніх вчителів інформатики початкової школи як платформи для курсу «Візуальне програмування» було використано LMS Moodle. Упровадження саме такого змішаного стилю викладання розпочалося з 2012-2013 н. р. і триває й до сьогодні. Здійснимо огляд покрокової адаптації зазначеного вище курсу 3 аналізом отриманих результатів на різних етапах викладання.

Середовище Moodle розгорнуто на адресою http://ikt.itup.com.ua/. Pecypc розміщено на пропрієтарному хостингу, а за доменне ім я використовується піддомен другого рівня Центру інноваційних технологій виховного процесу Національної академії педагогічних наук України при Рівненському державному гуманітарному університеті.

Для збору веб-аналітики використано плагіни, можливості яких більш розлого проаналізовано в одній зі статей автора (Петренко, 2016) [10].

Усі обчислення, проаналізовані у пропонованій розвідці, здійснено за період вересень-грудень 2016 р., позаяк відповідно до навчального плану для здобуття освітнього ступеня «бакалавр» за напрямом підготовки 013 «Початкова освіта» 3 додатковою спеціалізацією «Інформатика», предмет «Візуальне програмування» викладається у 7-му семестрі.

Аналіз викладання курсу дав змогу визначити таку тенденцію: лекційні заняття відвідувало в середньому 55-60 \% студентів, у той час як якісна успішність склала понад 70 \%. Варто зауважити, що здійснюючи обчислення, ми не враховували тих студентів, які навчалися за індивідуальним планом навчання (23\% студентів). Водночас, кількість унікальних відвідувань сторінок 3 лекційними матеріалами коливається від 23 до 30 переглядів. Тобто, щонайменше 77 \% студентів переглядали лекційні матеріали, які були доступні он-лайн.

Перше, на чому варто зосередити увагу, це співвідношення потраплянь студентів на сайт, де розміщений курс (табл. 1). Тут беззаперечним лідером є прямий вхід. Адже наш навчальний ресурс немає сторінок у жодній з існуючих соціальних мереж, а також не ведеться ніяка робота з оптимізації чи просування ресурсу серед пошукових систем. 
Таблиия 1

\section{Співвідношення потраплянь студентів на сайт, де розміщений курс}

\begin{tabular}{|c|c|}
\hline Джерело & Відсоткова ставка \\
\hline прямий вхід & $91.2 \%$ \\
\hline vk.com & $7 \%$ \\
\hline пошукові системи & $2.8 \%$ \\
\hline
\end{tabular}

Аналізуючи результати використання LMS Moodle, зауважимо, що використання відеороликів для навчальних цілей відіграє досить вагому роль, особливо, якщо мова йде про навчання використанню певного програмного продукту. Адже більшість студентів визнає той факт, що у них немає звички робити нотатки, незалежно від методу навчання (90\%) [15]. У зв'язку із зазначеним вище, а також базуючись на досвіді попередніх років впровадження курсу, нами було прийнято рішення розпочати створення коротких відеоуроків. Зважаючи, що створення інформативного контенту це досить довготривалий процес, ми підготували один відеоурок на початок курсу. Відеоряд містив детальні інструкції зі встановлення програмного забезпечення на ОС сімейства Windows (на прикладі Windows 7). Зібрані метрики констатують той факт, що 87 \% студентів переглядали відеоурок, попри те, що детальну інструкцію було надано й під час лекційних занять. І лише $6 \%$ респондентів повторно звернулися безпосередньо до викладача через проблеми при інсталяції продукту. Варто зазначити, що в усіх випадках повторного звернення проблема полягала у негараздах саме 3 операційною системою і наявністю різного роду вірусів на пристроях. Відтак, можемо констатувати, що грамотно і якісно підготовлені відеоуроки можуть внести якісні зміни в існуючий контент навчальних курсів i гармонійно доповнити будь-який формат викладу матеріалу.

Після грунтовного аналізу впливу он-лайн уроків і доведення їх позитивної ролі, ми вирішили започаткувати он-лайн тренінги з окремих тем. На момент написання статті нами було проаналізовано та встановлено програмне забезпечення, яке надасть змогу впровадити таку форму роботи [11]. Аналіз і деталі впровадження описаної форми роботи вважаємо перспективами майбутніх наукових розвідок. Ключові ж технічні аспекти з підготовки інтеграції висвітлені нами у статті «Ключові аспекти інтеграції BigBlueButton 3 LMS Moodle. Огляд функціональних можливостей системи он-лайн конференцій» (2016) [11].

Досить інформативними $є$ результати аналізу кількості часу, проведеного на ресурсі студентами до отримання ними підсумкових оцінок. Зокрема, на рис. 1 представлено дані десяти студентів (серед них один тестовий користувач, який спеціально додається нами до кожної групи щороку «UserDemo» - використовується виключно з метою перевірки існуючого функціоналу та інших технічних аспектів). Як видно з рис. 1, усі 9 реальних студентів перебували на ресурсі в цілому не менше 10 годин. При цьому зазначимо, що лише три студенти мали у своєму активі по одному пропущеному лабораторному заняттю, усі ж решта не мали жодного пропуску. На нашу думку, це свідчить про те, що студенти у своїй більшості відвідують он-лайн курс не через відсутність конспектів, а задля глибшого опанування курсу, а також про те, що пропоновані нетрадиційні методи навчання (принаймні у нашому регіональному ВН3), які надає LMS Moodle, без сумніву, більш цікаві сучасному студенту. 


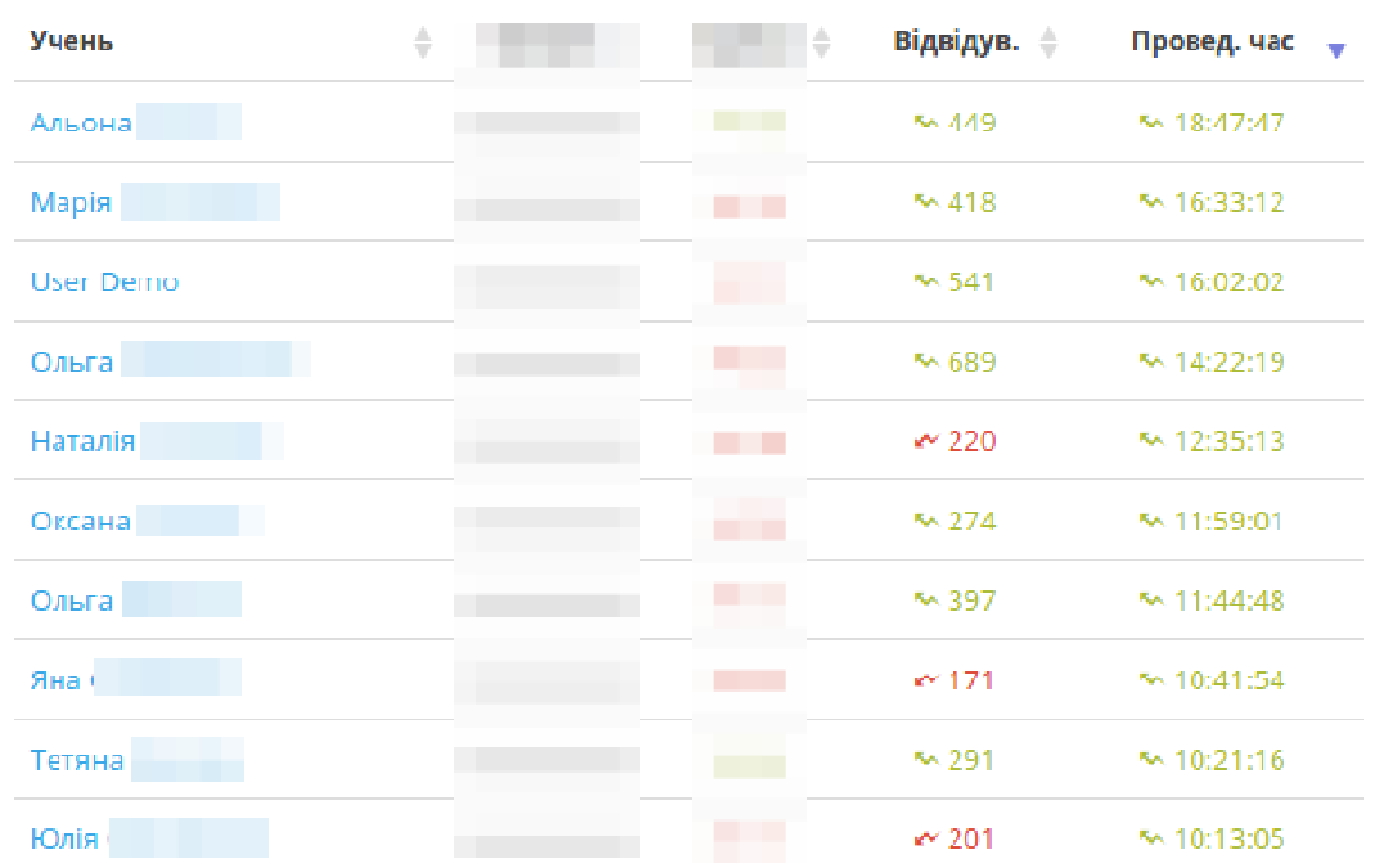

Рис. 1. Результати аналізу кількості часу, проведеного на ресурсі студентами

Що ж стосується підсумкових оцінок, то всі студенти, імена яких зазначено на рис. 1, закінчили курс з оцінкою за шкалою ECTS A або ж В.

На рис. 2 пропонуємо сумарну активність студентів на сайті за період викладання курсу в проміжку від 1 вересня до 31 грудня 2016 року.

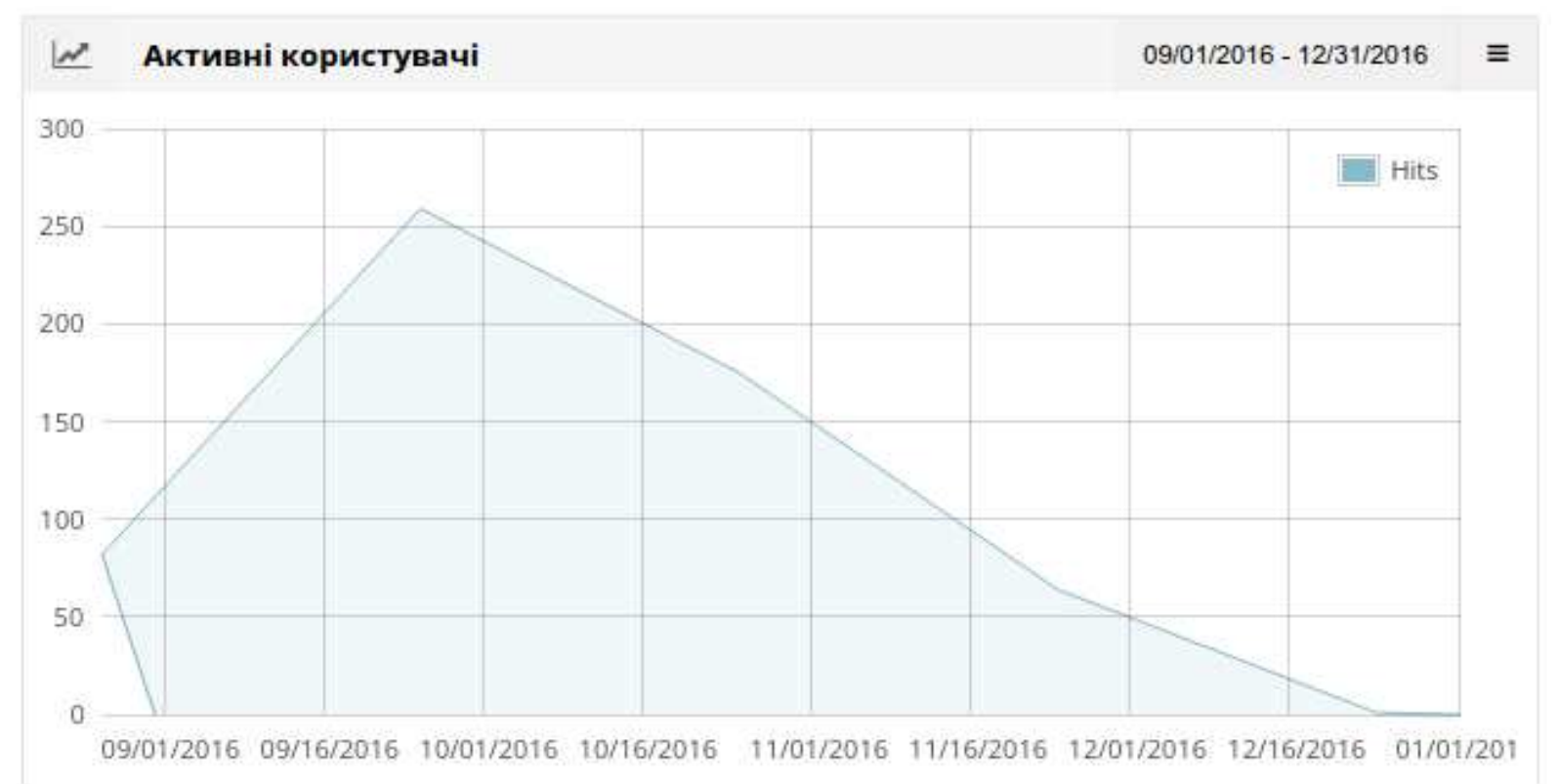

Рис. 2. Сумарна активність студентів на сайті (період 1.09.16 - 31.12.16)

А на рис. 3. пропонуємо кореляцію між унікальними відвідуваннями та кількістю переглянутих сторінок курсу. 


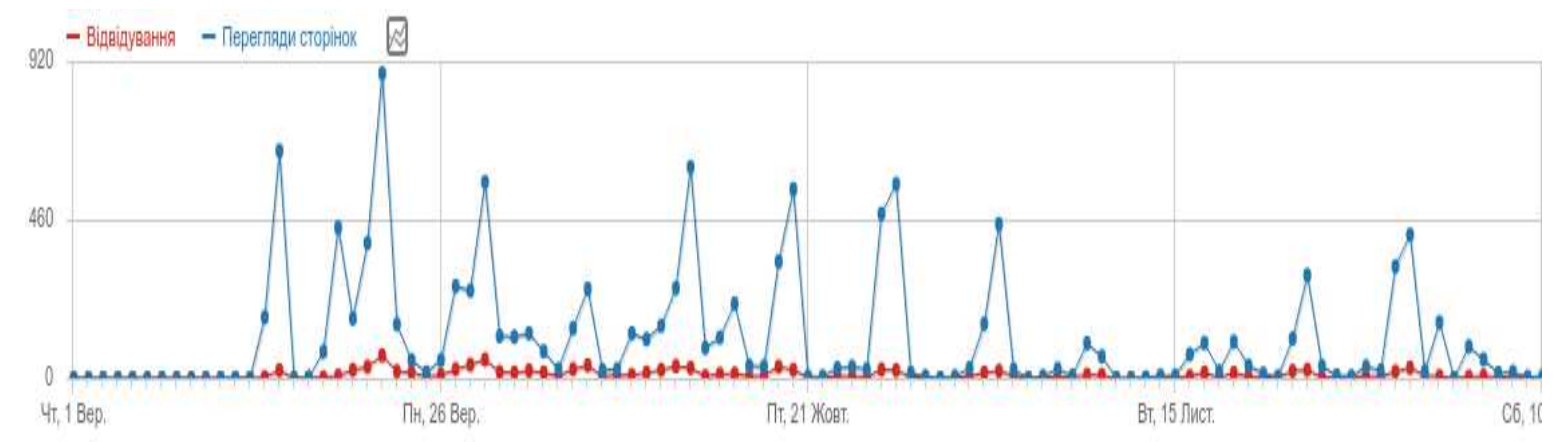

Рис. 3. Кореляція відвідувань до кількості переглянутих сторінок

За період упровадження курсу (2012-2016 рр.) ми виявили тенденцію до збільшення відвідувань нашого ресурсу 3 мобільних пристроїв (смартфони та планшети). Якщо за період 2012-2013 н. р. відвідувань з мобільних пристроїв було лише $3,6 \%$ iз середнім часом перебування до 2-х хв., то на сьогодні ці показники сягнули $13.9 \%$ ч часом перебування до 15 хв. Стрибок у кількості відвідувань 3 мобільних пристроїв, безумовно, тісно пов'язаний з глобальною комп’ютеризацією населення, у першу чергу, студентства.

Відповідно, якісних позитивних зрушень за усередненими показникам активності студентів на сайті саме 3 мобільних пристроїв ми змогли добитися завдяки адаптивному дизайну нашого ресурсу. При першій спробі використати адаптивний шаблон ми помітили приріст лише на 1,5 хвилини, а це, у свою чергу, вказувало на невдало обраний нами шаблон. Уже на наступний навчальний семестр ми використали відому теку Essential, яка вважається однією з найуспішніших згідно даних Moodle консорціуму (близько 14 тис. скачувань за останні 90 днів на момент написання статті [16]). Простий і водночас повнофункціональний, порівняно з версією для РС, шаблон дав змогу збільшити час перебування студентів у два рази, що вважаємо досить хорошим результатом. Варто зазначити, що при зміні шаблонів контент курсу не змінювався. Підтвердження отриманих результатів також знаходимо у праці іспанських вчених «AnalyzingMoodle/LMS LogstoMeasureMobile Access» [17].

Якщо ж проаналізувати операційні системи, з яких найчастіше відбувається звернення до нашого ресурсу, то трійку лідерів тримають продукти компанії Microsoft (Windows 7, 10 та 8.1 відповідно), далі ж розташувалась операційна система Android різних версій.

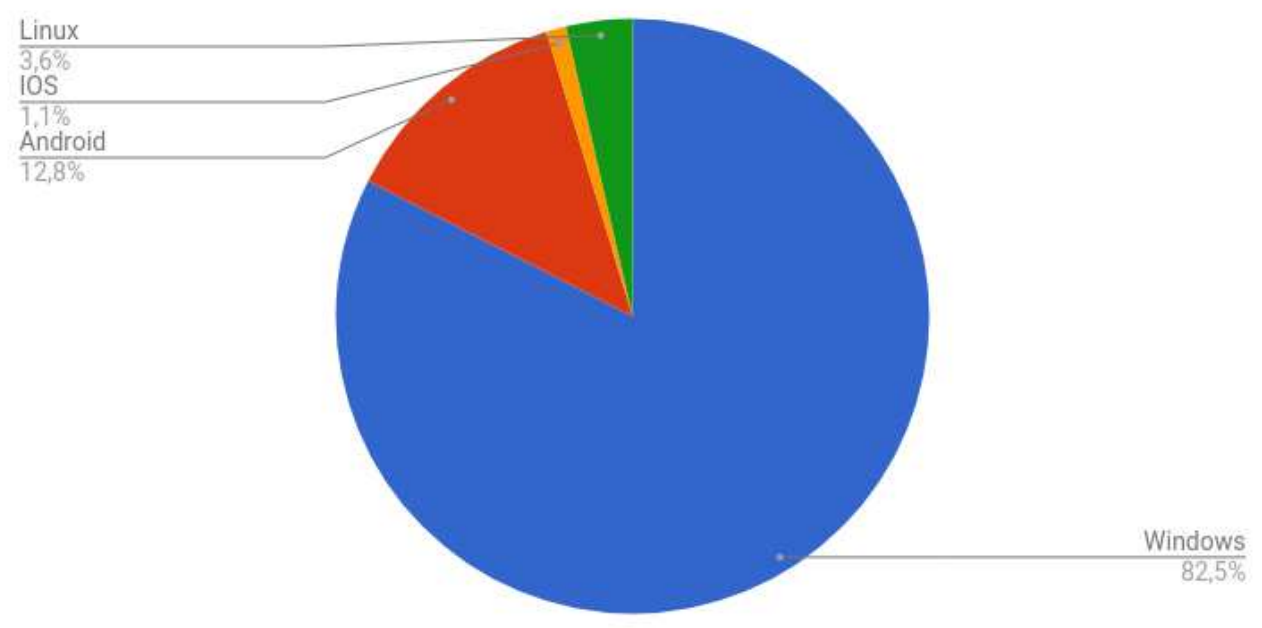


Рис. 4. Співвідношення операційних систем, з яких відбувалось звернення до ресурсу

На рис. 4 показано графічне співвідношення операційних систем, 3 яких здійснювалось відвідування сайту. Система Linux використовувалася нами для адміністрування ресурсу, тому показники до аналізу ми не включали.

Ще один вектор аналізу засвідчив, що більше 80 \% студентів використовують браузер Google Chrome, адже згідно даних StatCounterGlobalStats в Україні цей показник рівний 58,12 \% (червень 2017 року) [18]. Аналіз цих показників дав нам змогу здійснити цільове тестування оновлення системи саме в цьому браузері, адже за браком часу дуже важко підтримувати відповідність хоча б у більшості браузерів, які нині пропонує ринок. На рис. 5 пропонуємо гістограму, яка ілюструє співвідношення браузерів, що використовувались для роботи з нашим ресурсом.

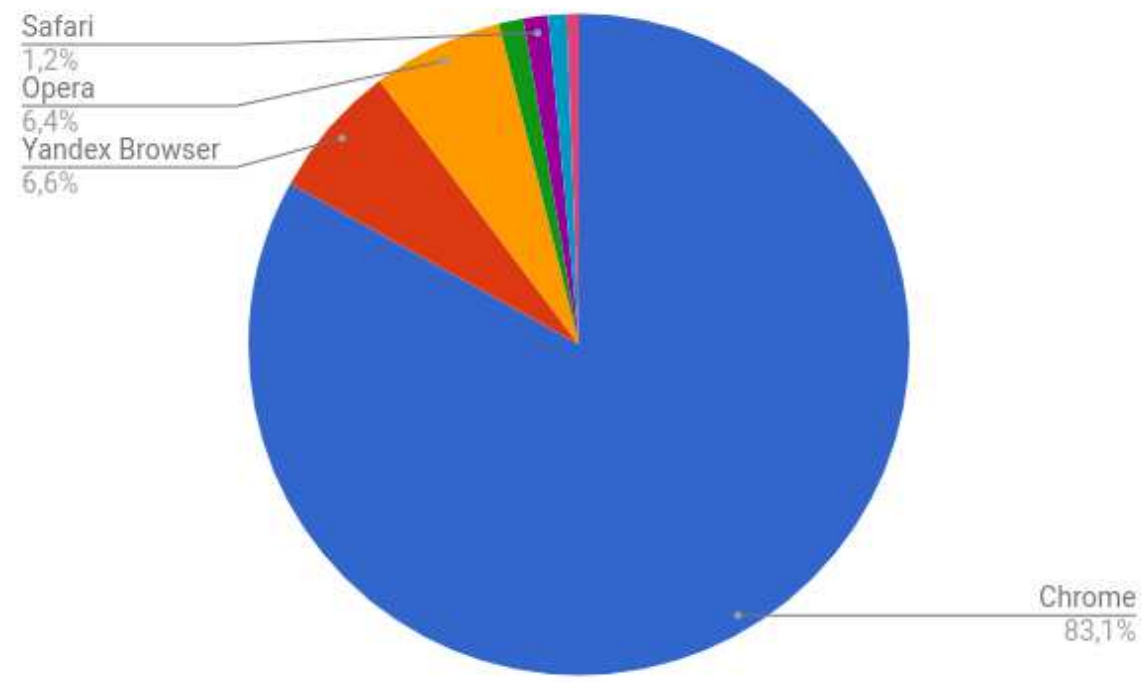

Рис. 5. Співвідношення браузерів, які використовувались для роботи з ресурсом

Наступною метрикою для аналізу ми обрали відвідування ресурсу за місцевим часом. Виявилося, що пік активності припадає на 17-19 год., потім активність дещо знижується і знову зростає після 21 год. Активність до 13 години зумовлена тим, що навчання проводилось у першу зміну. Графік відвідувань зображено на рис. 6.

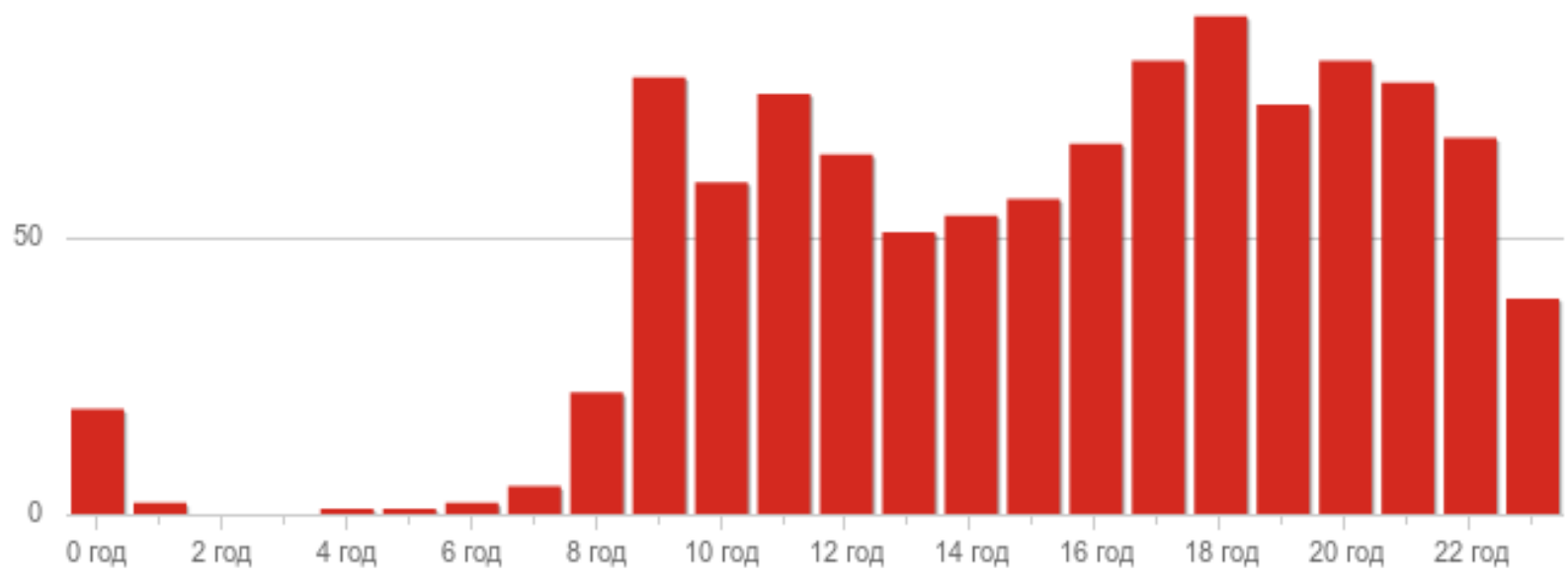




\section{Рис. 6. Графік відвідування ресурсу за місиевим часом}

Отримані й проаналізовані результати дали нам змогу обрати оптимальний час для поновлень і технічних правок на ресурсі. Відтак, кількість скарг щодо обмежень роботи із системою нам вдалось знизити до 0. Зауважимо, що декларуючи нульовий показник, маємо на увазі збої, що були спричинені технічними роботами, які проводили адміністратори ресурсу. Планові технічні обслуговування хостингових серверів, як правило, проводились за попереднім повідомленням i, відповідно, така інформація розсилалась студентам.

Здійснений аналіз дає змогу стверджувати, що процес підготовки майбутніх учителів інформатики початкової школи у ВНЗ, який здійснюється на основі спеціально розробленої методичної системи змішаного навчання, що побудована на платформі Moodle та включає розроблене методичне забезпечення, $\epsilon$ ефективним i забезпечує підвищення рівня фахової підготовки студентів.

Аналізуючи результати оптимізації використання LMS Moodle у системі змішаного навчання у ВНЗ було відзначено позитивні аспекти такого використання: створення й удосконалення електронних курсів; підвищення мотивації до вивчення дисциплін у форматі змішаного навчання у студентів; зростання рівня поінформованості викладачів і студентів про можливості LMS Moodle; удосконалення навичок роботи 3 LMS Moodle як викладачів, так і студентів; можливість автоматизованого тестування тощо.

Водночас, здійснений аналіз дав змогу виявити й систематизувати проблеми, пов'язані зі змішаним навчанням, які потребують вирішення, як-то: невисока якість навчального матеріалу, проблеми співпраці, неефективне управління часом, відсутність самодисципліни, технічні проблеми, труднощі у використанні платформи електронного навчання тощо.

\section{4. ВИСНОВКИ ТА ПЕРСПЕКТИВИ ПОДАЛЬШИХ ДОСЛІДЖЕНЬ}

Отже, аналіз результатів використання LMS Moodle у системі змішаного навчання у ВНЗ дає змогу зробити певні висновки й узагальнення: змішане навчання постійно вдосконалюється і спрямовується на підтримку особистісно-орієнтованого навчання. Оптимізація цього виду навчання сприяє розвитку мобільності студентів, посилення зорієнтованості на студента, збільшення кількості студентів, залучених до цього виду навчання, розширення можливостей взаємодії викладача і студента у віртуальному середовищі, збільшення автономності студентів за рахунок самостійної роботи 3 великою кількістю баз даних, які пропонуються в Інтернеті, персоналізація навчання, широке поширення доступу до мобільних пристроїв, які реалізують змішане навчання.

Технічні можливості системи навчання Moodle дають змогу використовувати iii для ефективного навчання студентів. Різноманіття форм подання матеріалу та зручність доступу до нього студентам, а також широкі можливості щодо керування навчальними курсами та їх вмістом роблять систему Moodle зручним інструментом для здійснення змішаного навчання.

Аналіз досвіду впровадження і використання LMS у вивченні курсу «Візуальне програмування» показав, що змішана форма дистанційного навчання на базі платформи Moodle найбільш адекватна вимогам розвитку України в рамках Європейської освіти.

Власний досвід свідчить, що змішане навчання вимагає підвищення кваліфікації викладача з використанням відкритих дистанційних курсів та поступової підготовки студента до навчального процесу у нових умовах. 
Результати аналізу впровадження LMS Moodle в РДГУ показують, що для широкого поширення змішаного навчання на платформі Moodle як технології змін i трансформацій необхідні певні уміння як викладачів, так і студентів. Такого роду моделі навчання надають якісного розвитку освіті, вони ефективніші, доступніші, ніж традиційні методи, забезпечують персональний підхід і з часом зможуть їх замінити.

Перспективи подальших розвідок вбачаємо в аналізі й удосконаленні власного навчального ресурсу на базі LMS Moodle шляхом розширення його функціональних можливостей, у сприянні викладачам ВНЗ педагогічного профілю щодо створення i викладання дистанційних та змішаних курсів з використанням LMS Moodle у BH3.

\section{СПИСОК ВИКОРИСТАНИХ ДЖЕРЕЛ}

[1] Ю. В. Триус, І. В. Герасименко, та В. М. Франчук, Система електронного навчання ВНЗ на базі MOODLE: методичний посібник Черкаси, Україна, 2012.

[2] The top 20 most popular LMS software. [Електронний pecypc]. Доступно: http://www.capterra.com/learning-management-system-software/\#infographic.

[3] А. М. Анисимов, Работа в системе дистанционного обучения Мооdle. Учебное пособие. 2-е изд. испр. и дополн. Харьков, Украина: ХНАГХ, 2009.

[4] Л. Я. Гозман, и Е. Б. Шестопал, Дистанционное обучение на пороге XXI века. Ростов-н/Д., Россия: Мысль, 1999.

[5] В. Ю. Биков, "Проектний підхід і дистанційне навчання у професійній підготовці управлінських кадрів", Кримські педагогічні читання: Матеріали Міжнародної наукової конферениї, 2001, с. 3050. [Електронний ресурс]. Доступно: http://lib.iitta.gov.ua/498/1/Bykov1-2001.pdf. Дата звернення: Серп. 13, 2017.

[6] В. М. Кухаренко, та ін., Теорія та практика змішаногонавчання: монографія. Харків, Україна: Міськдрук, 2016.

[7] А. Є. Фандєєва, “Змішане навчання як технологія змін і трансформації” [Електронний ресурс]. Доступно: https://www.narodnaosvita.kiev.ua/?page_id=4544. Дата звернення: Серп. 13, 2017.

[8] О. А. Щербина, та К. С. Васильєва, "Проектування структури сайту moodle для вищого навчального закладу та організація робіт з його створення", Вісник Львівського державного університету безпеки життедіяльності, № 9, с. 35-40, 2014. [Електронний ресурс]. Доступно: http://nbuv.gov.ua/UJRN/Vldubzh_2014_9_7. Дата звернення: Серп. 13, 2017.

[9] К. Р. Колос, "Система Moodle як засіб розвитку предметних компетентностей учителів інформатики в умовах дистанційної післядипломної освіти", Інститут інформаційних технологій i засобів навчання НАПН України, Київ, Україна, 2011.

[10] С. В. Петренко, "Порівняльний аналіз найпопулярніших плагінів веб-аналітики для LMS Moodle", MoodleMootUkraine 2016, 2016 [Електронний pecypc]. Доступно: http://2016.moodlemoot.in.ua/course/view.php?id=98. Дата звернення: Серп. 13, 2017.

[11] С. В. Петренко, "Ключові аспекти інтеграції BigBlueButton з LMS Moodle. Огляд функціональних можливостей системи он-лайн конференцій”, MoodleMootUkraine 2017, 2017 [Електронний pecypc]. Доступно: http://2017.moodlemoot.in.ua/course/view.php?id=98. Дата звернення: Серп. 13, 2017.

[12] Закон України «Про національну програму інформатизації» (дата набуття чинності 12 березня 1998 р.) [Електронний ресурс]. Доступно: http://zakon4.rada.gov.ua/laws/anot/74/98- \%D0 \%B2 \%D1 \%80. Дата звернення: Серп. 13, 2017.

[13] Концепція розвитку дистанційної освіти в Україні (затверджено Постановою МОН України 20 грудня 2000 р.) [Електронний ресурс]. Доступно: http://www.zakon.rada.gov.ua. Дата звернення: Серп. 13, 2017.

[14] Дистанційне навчання - від теорії до практики, актуальний мережевий семінар [Електронний pecypc]. Доступно: http://www.osvita.org.ua/distance/articles/15/. Дата звернення: Серп. 13, 2017.

[15] D Airinei, and D Homocianu, "The importance of video tutorials for higher education - the example of business information systems", Quality management in higher education, Book 2, pp. 345-348, 2010.

[16] Moodle plugins directory: Essential - Moodle.org [Електронний pecypc]. Доступно: https://moodle.org/plugins/theme_essential. Дата звернення: Серп. 13, 2017.

[17] María José Casany, Marc Alier, Nikolas Galanis, EnricMayol, and Jordi Piguillem, "Analyzing Moodle/LMS Logs to Measure Mobile Access", The Sixth International Conference on Mobile Ubiquitous Computing, Systems, Services and Technologies [Електроннийресурс]. Доступно: 
https://upcommons.upc.edu/bitstream/handle/2117/19058/ubicomm_2012_2_30_10119_publicat.pdf. [18] StatCounterGlobalStats [Електронний ресурс]. Доступно: http://gs.statcounter.com/.

Матеріал надійшов до редакиії 13.08.2017 p.

\title{
ОПТИМИЗАЦИЯ И АНАЛИЗ РЕЗУЛЬТАТОВ ИСПОЛЬЗОВАНИЯ LMS MOODLE В СИСТЕМЕ СМЕШАННОГО ОБУЧЕНИЯ В УНИВЕРСИТЕТЕ
}

\author{
Петренко Сергей Викторович \\ кандидат педагогических наук, старший преподаватель кафедры информационно-коммуникационных \\ технологий и методики преподавания информатики \\ Ровенский государственный гуманитарный университет, г. Ровно, Украина \\ ORCID ID 0000-0002-5311-0743 \\ petrenko.zd@gmail.com
}

\begin{abstract}
Аннотация. В статье обоснованы теоретические основы е-обучения, дистанционного и смешанного обучения; проанализирован опыт использования смешанного стиля преподавания курса «Визуальное программирование», где в качестве платформы было использовано LMS Moodle. Выяснены положительные и негативные аспекты реализации курса с помощью веб-аналитики. Проанализировано: посещаемость курса и успеваемость студентов; соотношение попаданий студентов на сайт, на котором размещен курс; использование он-лайн уроков, он-лайн тренингов по отдельным темам; количество времени, проведенное на ресурсе студентами; суммарную активность студентов на сайте; корреляцию между уникальными посещениями и количеством пересмотренных страниц курса; посещение ресурса из мобильных устройств; операционные системы, из которых происходило обращение к ресурсу; соотношение браузеров, которые использовались для работы с ресурсом; посещение ресурса по местному времени.
\end{abstract}

Ключевые слова: е-обучение; дистанционное обучение; смешанное обучение; LMS Moodle; он-лайн уроки; мобильные устройства; учитель информатики начальной школы.

\section{OPTIMIZATION AND ANALYSIS OF THE RESULTS OF USING LMS MOODLE IN THE MIXED LEARNING SYSTEM IN UNIVERSITY}

\author{
Serhii V. Petrenko \\ $\mathrm{PhD}$, senior lecturer of ICT and methods of teaching of computer science department \\ Rivne State University of Humanities, Rivne, Ukraine \\ ORCID ID 0000-0002-5311-0743 \\ petrenko.zd@gmail.com
}

\begin{abstract}
In the article the author substantiates the theoretical foundations of e-learning, distance learning and mixed learning. We have analyzed the experience of using a mixed style of teaching a course, where LMS Moodle was used as a platform. The author shows positive and negative aspects of the implementation of the course using web analytics. We analyzed attendance of the course and student success; the ratio of student hits to the site where the course is located; use of on-line lessons, on-line training on selected topics; amount of time spent on resources by students; total student activity on the site; the correlation between unique visits and the number of pages viewed; visiting a resource from mobile devices; operating systems, from which there was an appeal to the resource; the ratio of browsers that were used to work with the resource; visiting the resource in local time.
\end{abstract}

Keywords: e-learning; distance learning; mixed learning; LMS Moodle; online lessons; mobile devices; elementary school computer science teacher. 


\section{REFERENCES (TRANSLATED AND TRANSLITERATED)}

[1] Yu. V. Tryus, I. V. Herasymenko, ta V. M. Franchuk, Educational system of education in higher education on MOODLE: a methodical guide.Cherkasy, Ukraine, 2012. (in Ukrainian)

[2] A. M. Anysymov, Work in the system of distance learning Moodle. Tutorial. 2 nd ed. Correction. And add.Har'kov, Ukraina: HNAGH, 2009. (in Russian)

[3] L. Ja. Gozman, i E. B. Shestopal, Distance learning on the threshold of the XXI century.Rostov-n/D., Rossija: Mysl', 1999. (in Russian)

[4] V. Yu. Bykov, "Project approach and distance learning in the professional training of managerial personnel”, Krymski pedahohichni chytannia: Materialy Mizhnarodnoi naukovoi konferentsii, 2001, s. 30-50. [Online]. Available: http://lib.iitta.gov.ua/498/1/Bykov1-2001.pdf. Accessed on: Aug. 13, 2017. (in Ukrainian)

[5] V. M. Kukharenko, ta in., Theory and practice of mixed learning: a monograph. Kharkiv, Ukraina: Miskdruk, 2016. (in Ukrainian)

[6] A. Ie. Fandieieva, "Mixed learning as a technology of change and transformation" [Online]. Available: https://www.narodnaosvita.kiev.ua/?page_id=4544. Accessed on: Aug. 13, 2017. (in Ukrainian)

[7] O. A. Shcherbyna, ta K. S. Vasylieva, "Designing a moodle site for a higher educational institution and organizing works on its creation", Visnyk Lvivskoho derzhavnoho universytetu bezpekyz hyttiediialnosti, \# 9, s. 35-40, 2014. [Online]. Available: http://nbuv.gov.ua/UJRN/Vldubzh_2014_9_7. Accessed on: Aug. 13, 2017. (in Ukrainian)

[8] K. R. Kolos, "Moodle System as Way of Development of Teachers' of Informatics Subjective Competences in the Cases of Distant Postgraduate Education", Instytut informatsiinykh tekhnolohii i zasobiv navchannia NAPN Ukrainy, Kyiv, Ukraina, 2011. (in Ukrainian)

[9] S. V. Petrenko, "A comparative analysis of the most popular web analytics plugins for LMS Moodle", Moodle Moot Ukraine 2016, 2016 [Online]. Available: http://2016.moodlemoot.in.ua/course/view.php?id=98. Accessed on: Aug. 13, 2017. (in Ukrainian)

[10] S. V. Petrenko, "Key aspects of BigBlueButton integration with LMS Moodle. An overview of the functionality of the system of on-line conferences", Moodle Moot Ukraine 2017, 2017 [Online]. Available: http://2017.moodlemoot.in.ua/course/view.php?id=98. Accessed on: Aug. 13, 2017. (in Ukrainian)

[11] Moodle plugins directory: Essential - Moodle.org [Online]. Available: https://moodle.org/plugins/theme_essential. Accessed on: Aug. 13, 2017. (in Ukrainian)

[12] Law of Ukraine "On the National Program of Informatization" (date of entry into force March 12, 1998) [Online]. Available: http://zakon4.rada.gov.ua/laws/anot/74/98- \%D0 \%B2 \%D1 \%80. Accessedon: Aug. 13, 2017. (in Ukrainian)

[13] Concept of development of distance education in Ukraine (approved by the Resolution of the Ministry of Education and Science of Ukraine on December 20, 2000). [Online]. Available: http://www.zakon.rada.gov.ua. Accessed on: Aug. 13, 2017. (in Ukrainian)

[14] Distance learning - from theory to practice, topical networking seminar [Online]. Available: http://www.osvita.org.ua/distance/articles/15/. Accessed on: Aug. 13, 2017. (in Ukrainian)

[15] D Airinei, and D Homocianu, "The importance of video tutorials for higher education — the example of business information systems", Quality management in higher education, Book 2, pp. 345-348, 2010. (in English)

[16] María José Casany, Marc Alier, Nikolas Galanis, EnricMayol, and Jordi Piguillem, "Analyzing Moodle/LMS Logs to Measure Mobile Access", The Sixth International Conference on Mobile Ubiquitous Computing, Systems, Services and Technologies [Online]. Available: https://upcommons.upc.edu/bitstream/handle/2117/19058/ubicomm_2012_2_30_10119_publicat.pdf. Accessedon: Aug. 13, 2017. (in English)

[17] StatCounter Global Stats [Online]. Available: http://gs.statcounter.com/. Accessedon: Aug. 13, 2017. (in English)

[18] The top 20 most popular LMS software. [Online]. Available: http://www.capterra.com/learningmanagement-system-software/\#infographic. Accessedon: Aug. 13, 2017. (in English)

\section{$($ (c) ) BY-NC-SA}

This work is licensed under Creative Commons Attribution-NonCommercial-ShareAlike 4.0 International License. 